\title{
Immunomodulatory Potentials of Winged Bean (Psophocarpus tetragonolobus) Bioactive Compounds on Human Lymphocyte Proliferation
}

\author{
Arindra Nirbaya ${ }^{a}$, Fransiska Rungkat Zakaria ${ }^{a}$,", Hendra Wijaya ${ }^{b}$, Erniati $^{c}$ \\ ${ }^{a}$ Department of Food Science and Technology, Faculty of Engineering, IPB University, Bogor-16680, Indonesia \\ ${ }^{b}$ Center for Agro-based Industry, Ministry of Industry, Bogor-16122, Indonesia \\ ${ }^{c}$ Agriculture Faculty, Malikussaleh University, Aceh, Indonesia \\ Corresponding author: ${ }^{*}$ since@apps.ipb.ac.id
}

\begin{abstract}
Winged bean (Psophocarpus tetragonolobus) has been reported to consist of many bioactive compounds that can improve the human immune system. Food preparation using heat treatment applied typically can change the bioactive properties of the bean. These studies' main aims were to analyze antioxidants activity and immunomodulatory effect of young winged bean pods and mature winged beans, boiled or canned on human lymphocytes, representing the immune system. The samples were extracted using three-stage maceration methods with n-hexane, ethyl acetate, and water. The extracts were cultured with lymphocyte cells using various concentrations representing normal consumption. IL-2 representing cell proliferation was analyzed using ELISA. Cell marker proteins CD4+, CD8+, CD3+, CD19, and CD16/56 were analyzed using a flow cytometer. The highest antioxidants activity was on the water extract of raw mature bean $(7.2175 \pm 0.4794 \mathrm{mg} \mathrm{AAE} / \mathrm{g})$. The boiling process increased young winged bean anti-oxidant activity $(\mathrm{P}<0.05)$, but decreases the anti-oxidant activity of the mature bean $(\mathrm{P}<0.05)$. The highest proliferation indexes were obtained from water extracts of both boiled (2.13) and canned mature bean (2.12). Water extracts of all samples increased expressions of IL-2, CD4+, CD8+, CD3+, CD19 and CD16/56 on the cell surface. Boiled young winged bean pods have the best activity in increasing CD19 marker. Canned mature bean was effective in increasing CD16/56 expression. Boiling and canning of both young and mature winged beans can increase the immune system as shown by the immune parameter analyzed.
\end{abstract}

Keywords —anti-oxidant; lymphocytes; proliferation; protein markers; boiling.

Manuscript received 2 Apr. 2020; revised 15 Feb. 2021; accepted 24 Feb. 2021. Date of publication 30 Jun. 2021. IJASEIT is licensed under a Creative Commons Attribution-Share Alike 4.0 International License.

\section{INTRODUCTION}

Central Statistics Agency (BPS) reports that from 2000 to 2017 , Indonesia's morbidity rate was $28.6 \%$, mainly consisted of non-communicable diseases (NCD) and other acute diseases [1]. NCD has been reported to be a worldwide problem that healthy diets could prevent consisted mostly of plant-based foods [2], [3]. Research on the benefit of plant foods for health or functional foods has been done substantially. Food has various bioactive compounds such as flavonoids, carotenoids, phenolic acids, and terpenoids. The mixtures of bioactive compounds in foods have synergistic properties on the level of cell proliferation, apoptosis, antioxidant capacity [4]. Consumption of spices, vegetables, and fruits in sufficient quantities was able to show antiinflammatory effects and increase the immune system in humans, such as in healthy students and factory worker respondents [5]. This occurred due to an increase in immune cells functions including proliferation activity, increasing in subset cell numbers such as CD4+ and CD8-T cells and cytotoxic activity of natural killer cells (NK) or CD16/56Tcell.

Indonesia's people widely consume young winged bean pods (Psophocarpus tetragonolobus) as raw, boiled, or stirfried whole pod vegetables. The mature bean is not as widely used as the young but incidentally used as a common bean dish. Recently, mature winged bean grown locally was characterized for its functional and physicochemical properties [6], [7]. The leaf of the plant is consumed as a salad in Sri Lanka. Similar uses occur in Papua New Guinea on winged flowers. Winged tubers are consumed in Burma and Papua New Guinea as steamed, roasted, and boiled preparations [8]. Winged bean, Psophocarpus tetragonolobus (L.) DC. is analogous to soybean in yield and nutritional 
quality, proving a valuable alternative to soybean in tropical regions of the world. The nutrient content in the winged bean is almost the same as in soybeans in protein and fat [9], [10]. Bioactive components of a winged bean are also high in vitamin $\mathrm{A}$, vitamin $\mathrm{C}$, calcium, iron, flavonoid, and phenolic components [6], [11].

Bioactive components in wing beans can provide antioxidant, anti-inflammatory, antinociceptive, antibacterial, antifungal, antiproliferative, cytotoxic activity antihypertensive effect [12]-[15]. Bioactive compounds act as a defense against oxidants and metabolic deregulation and immune-modulating [16]-[18]. The oxidant inhibition and immune-modulating effects of the cellular system have an anti-inflammatory effect and modulate the immune reactions [19]. This mechanism occurs as a result of polyphenols inhibiting enzyme activity associated with pro-inflammatory agents such as cyclooxygenase-2 (COX-2), lipoxygenase (LOX), and inducible nitric oxide synthase (iNOS) in producing cytokines or inducing cell death [20]. Besides, polyphenols can also inhibit the nuclear factor kappa-lightchain-enhancing activated $\mathrm{B}$ cells $(\mathrm{NF}-\mathrm{kB})$, induce activation of protein-1 (AP-1), activate phase II detox enzymes, and mitogen-activated protein kinase (MAPK), protein kinase C, and nuclear factor erythroid-2 (Nrf-2) [21]. Faba bean extract was shown to inhibit Cox-2 enzyme activity with IC50 at 119 $\mathrm{ug} / \mathrm{mL} 21$. In diabetic respondents, black soybean increased IL-6 from 0,23 to 0,25 , CD4+Tcell from 563 to 679 and CD8+Tcell from 317 to 343 [19]. Mung bean processed by fermentation and soybean possessed cytotoxicity activities against breast cancer MCF-7 cells by apoptosis and inducing splenocyte proliferation and increasing serum cytokines interleukin-2 and interferon- $\gamma$ levels [22].

Food processing improves the flavor and palatability of beans and changes the character of bioactive compounds and its functional properties. Beans were soaked to soften the texture and shorten cooking time. On the other hand, soaking could reduce polar bioactive compounds [23]-[25]. The bioactive compound is quite susceptible to heat and is easily dissolved in water [26]. The opportunity for the biological benefits of the bioactive components of winged bean that has undergone processing needs to be studied. This study aims to determine the antioxidant activity and immunomodulatory effects of the bioactive compound of processed winged beans on human lymphocyte cells in vitro to explore their potential in modulating the immune responses.

\section{MATERIAL AND METHODS}

\section{A. Plant Material}

Winged beans (Psophocarpus tetragonolobus) were obtained from local farmers in Caringin, Bogor, Indonesia. Winged beans were collected at 3 weeks and 8 weeks after flowering (WAF). Whole pod 3 WAF winged beans were used as young bean samples. Beans of 8 WAF were used as mature bean samples. Broken pods and beans, foreign materials were hand removed from the samples.

\section{B. Processing}

Winged bean pods were washed and cut at approximately $\pm 2 \mathrm{~cm}$. The samples were added water (1:4) and then boiled for 15 minutes. The mature winged beans were soaked 18 hours at ambient temperature, then boiled and canned. Boiled beans were produced by washing and then boiling for 70 minutes by adding water 1:10. The canning process to get ready-to-eat beans were done, as reported by Setyawan et al. [7]. Raw and cooked winged samples were oven-dried at $50^{\circ} \mathrm{C}$ for 24 hours. The dried samples were ground and pressed to pass through 4 mesh $(5 \mathrm{~mm})$ sieve. Later, the powder samples were preserved in polyethylene bags and store at the refrigerator for further analysis.

\section{Bioactive Compound Extraction from Raw and Processed Winged Beans}

Sample extraction was carried out in stages using three types of solvents. 50 grams of sample powder was mixed with $200 \mathrm{~mL}$ of hexane. The extraction process was carried out by sonication for 15 minutes and then in a shaker for 24 hours at room temperature, speed $150 \mathrm{rpm}$. The solution was filtered then the solid residue was re-extracted with the same solvent and method three times to obtain a non-polar filtrate. The residue was re-extracted to get semi-polar using ethyl acetate and polar water extracts. Hexane and ethyl acetate extracts were concentrated using a rotary evaporator (Buchi R II) at $40^{\circ} \mathrm{C}$, speed 75 , rpm, and vacuum condition. While the water extract was concentrated using a rotary evaporator (Buchi R II) at $50^{\circ} \mathrm{C}$, speed $80 \mathrm{rpm}$, and vacuum condition [27].

\section{Anti-oxidant Activity Test of FRAP Method}

FRAP reagent was freshly prepared by mixing $300 \mathrm{mM}$ acetate buffer $\left(\mathrm{CH}_{3} \mathrm{COOH}+\mathrm{CH}_{3} \mathrm{COONa}\right) \mathrm{pH} 3.6$; 2,4,6Tri(2-pyridyl)-s-triazine (TPTZ) $10 \mathrm{mM}$ in $40 \mathrm{mM} \mathrm{HCl}$; $20 \mathrm{mM} \mathrm{FeCl} 3.6 \mathrm{H}_{2} \mathrm{O}$ with a ratio of 10:1:1. The extracts were dissolved in ethanol to a concentration of $1 \mathrm{mg} / \mathrm{mL}$. The diluted sample was pipetted $20 \mu \mathrm{L}$ into the 96 well plates and added $180 \mu \mathrm{L}$ FRAP reagent. The reaction mixture's absorption was measured using a microplate reader (Epoch BioTech) at $590 \mathrm{~nm}$. The absorbance measurements were compared with ascorbic acid in the range of $20-320 \mu \mathrm{g} / \mathrm{mL}$ as the calibration curve. The reducing power was expressed as milligram of ascorbic acid equivalent (mg AAE/g) of powder sample [28].

\section{E. Lymphocyte Isolation}

Peripheral blood was collected $20 \mathrm{ml}$ from a healthy male student after the University Ethical Committee approved the ethical clearance. The collected blood was transferred into a sterile centrifugation tube and continued with centrifugation at $1500 \mathrm{rpm}, 20^{\circ} \mathrm{C}$ for 10 minutes. The clear layer (buffy coat) between the yellow and red layers was pipetted and transferred to another tube then added with PBS (Sigma). The suspension is added to the tube containing the ficoll-hypaque (Sigma) solution through the tube wall slowly to form an overlayer then centrifuged at $2700 \mathrm{rpm}$ at a temperature of $20^{\circ} \mathrm{C}$ for 30 minutes. Layers as rings are piped and transferred to another tube to add PBS. The suspension is centrifuged at a speed of $2000 \mathrm{rpm}$, a temperature of $20^{\circ} \mathrm{C}$ for 30 minutes, and the cell pellet was washed with PBS twice by centrifugation at a speed of $2000 \mathrm{rpm}$ for 10 minutes. The cell pellets obtained were added with RPMI 1640 medium (Sigma) added with FBS (Sigma). The last process of isolation is counting the number of cells [16]. 
Calculation of cell counts was carried out with $10 \mu \mathrm{L}$ of cell added with $10 \mu \mathrm{L}$ triphan blue dye, then pipetted into the hemacytometer and observed using a microscope with 400 times magnification. Cells are calculated by considering 5 fields of view. The cells to be tested must be in a living condition of at least $1 \times 10^{6}$ cells $/ \mathrm{ml}$ [29].

\section{F. Cell Proliferation Test MTT Method}

A total of $80 \mu \mathrm{L}\left(10^{5}\right.$ cells $)$ of lymphocyte cell suspensions were pipetted into sterile microplate wells. The cell suspension was added with a test extract of $20 \mu \mathrm{L}$ with various concentrations and then incubated for 72 hours. With the condition of $5 \% \mathrm{CO}_{2}, 37{ }^{\circ} \mathrm{C}$ and humidity of $90 \%$. The level of sample concentration of young winged bean was 11.07 $\mathrm{mg} / \mathrm{mL} ; 5.53 \mathrm{mg} . \mathrm{mL} ; 2.77 \mathrm{mg} / \mathrm{mL}$. Whereas mature winged bean concentration levels were $6.4 \mathrm{mg} / \mathrm{mL} ; 3.2 \mathrm{mg} / \mathrm{mL} ; 1.6$ $\mathrm{mg} / \mathrm{mL}$. In other wells, PHA was added as a positive control and RPMI media as a negative control. Furthermore, MTT (5 $\mathrm{mg} / \mathrm{mL}$ ) was added $10 \mu \mathrm{L}$ in each well 4 hours before the incubation period ended. Ethanol p.a was added $100 \mu \mathrm{L}$ in each well after the incubation ended. The absorbance measurement was carried out by ELISA reader (BioGen) at a wavelength of $595 \mathrm{~nm}$ [30]. Proliferation activity is expressed in the proliferation index calculated by the equation:

$$
\text { Stimulation Index }=\frac{\text { Sample absorbance }}{\text { control absorbance }}
$$

\section{G. IL-2 Expression Test}

Interleukin-2 (iL-2) expression test was carried out using the ELISA method. $800 \mu \mathrm{L}$ ( $10^{6}$ cells) of the lymphocyte cell suspension was added into 12 well microplates, and $200 \mu \mathrm{L}$ of the extract solutions were added with the same concentration as for the proliferation test. Cell suspensions were incubated for 72 hours under conditions of $5 \% \mathrm{CO}_{2}, 37$ ${ }^{\circ} \mathrm{C}$ and humidity of $90 \%$. PHA was used as a positive control and RPMI as a negative control. After the incubation ended, the cell suspension was centrifuged for 10 minutes at a speed of $1500 \mathrm{rpm}$ at a temperature of $20^{\circ} \mathrm{C}$, and the supernatants were used to measure the expression of IL-2 using human IL2 ELISA kit (Elabscience). The amount of IL-2 is calculated based on the IL-2 standard curve [31].

\section{H. Analysis of CD3+, CD4+, CD8+, CD19+, CD16/56+Tcells}

$100 \mu \mathrm{L}$ of cell pellet suspension was pipetted and inserted into the falcon tube then added $20 \mu \mathrm{L}$ of human anti-CD3+, anti-CD4+, anti-CD8+, anti-CD19, anti-CD16/56 antibody reagent kits. The mixture was incubated at room temperature, dark conditions for 20 minutes, and fixation was carried out using a solution of a reagent kit containing diethylene glycol and formaldehyde. Cell pellets are shaken then added with PBS and read using a flowcytometry (BD FACS ${ }^{\mathrm{TM}}$ ) [19].

\section{Statistical Analysis}

The results were statistically analyzed by IBM SPSS Statistics 21 computer program. The data ware was assessed using one-way ANOVA followed by Duncan test to analyse the treated samples' significant level. P-values less than 0.05 were considered as statistically significant.

\section{J. Ethical Statement}

Human Research Ethics Committee approved the study of IPB University Bogor, Indonesia (Ethical clearance No. 033/IT3.KEPMSM-IPB/SK/2018, on 7th June 2018)

\section{RESULT AND DISCUSSION}

\section{A. Anti-oxidant Activity}

Anti-oxidants are defined as substances to fight or inhibit oxidation reactions induced by oxygen or peroxide. The method of testing anti-oxidant activity in this study used the FRAP method based on a compound's ability to reduce radical $\mathrm{Fe}$ (III) to Fe (II). The analysis results were compared with ascorbic acid in which 1 mole of ascorbic acid could reduce 2 moles of Fe (III). The higher the analysis results, the better the ability to deter free radicals. The anti-oxidant activities of various winged bean extracts are presented in Table 1 .

TABLE I

ANTI-OXIDANTS ACTIVITY OF VEGETABLE AND WINGED BEAN EXTRACTS USING ASCORBIC ACID (AA) AS STANDARD

\begin{tabular}{cccc}
\hline \multirow{2}{*}{ Sample } & \multicolumn{3}{c}{ Antioxidants Activity (mgAA/g) } \\
\cline { 2 - 4 } & n-hexana & Ethyl Acetate & Water \\
\hline RY & $0.33 \pm 0.08^{\mathrm{a}}$ & $0.50 \pm 0.01^{\mathrm{a}}$ & $5.39 \pm 0.65^{\mathrm{e}}$ \\
BY & $0.28 \pm 0.26^{\mathrm{a}}$ & $0.29 \pm 0.02^{\mathrm{a}}$ & $6.63 \pm 0.70^{\mathrm{f}}$ \\
RM & $2.89 \pm 0.09^{\mathrm{c}}$ & $0.74 \pm 0.01^{\mathrm{a}}$ & $7.21 \pm 0.47^{\mathrm{g}}$ \\
BM & $2.22 \pm 0.16^{\mathrm{b}}$ & $0.31 \pm 0.02^{\mathrm{a}}$ & $4.38 \pm 0.18^{\mathrm{d}}$ \\
CM & $2.07 \pm 0.24^{\mathrm{b}}$ & $0.33 \pm 0.02^{\mathrm{a}}$ & $5.24 \pm 0.07^{\mathrm{e}}$ \\
\hline
\end{tabular}

$\mathrm{RY}=$ raw young winged bean; $\mathrm{BY}=$ boiled young winged bean; $\mathrm{RM}=$ raw mature winged bean; $\mathrm{BM}=$ boiled mature winged bean; $\mathrm{CM}=$ canned mature winged bean. Different letters showed significant differences based on the Duncan post hoc test $(\mathrm{P}<0.05)$.

Young winged beans, normally consumed as a vegetable, have lower anti-oxidant activity compared to mature winged beans $(\mathrm{P}<0.05)$. The mature bean coat contains phenolic components that act as the first defense mechanism for UV and microbial exposure [32], pathogens, predators, and abiotic stress [33]. The existence of the phenolic component as one part of the bioactive component supports the statement of Boukhanouf et al. [34] that the highest anti-oxidant is found in the bean coat.

Heat exposure to vegetable beans increases anti-oxidant activity in the bean. This occurs due to the inactivation of oxidation enzymes such as peroxidase, which triggers prooxidants' formation and the formation of new compounds that can act as anti-oxidants. The same is true of other vegetables such as paprika, pumpkin, spinach, green beans and beetroot [35]. In detail, the decrease in anti-oxidant activity of canned beans was lower than in boiled beans. The heating process can cause the release of phenolic bonds and phenolic conversion into insoluble components bound to cell wall polysaccharides [34], [36]. Soaking the beans that were done before processing also has the potential to decrease anti-oxidant activity.

Solvents provide an important role in anti-oxidant testing because they are based on their ability to take all components that have anti-oxidant benefits [34]. Extraction with various solvents was carried out to obtain the distribution of bioactive components based on the level of polarity. Non-polar solvent hexane has polarity index 0.0 , semi-polar ethyl acetate 4.4 and 
polar water has polarity index 9.0. Water extracts had the highest anti-oxidant activity statistically $(\mathrm{P}<0.05)$ in both young and mature beans. Bean anti-oxidants were more dominant in hexane extract $(\mathrm{P}<0.05)$, while vegetable young bean anti-oxidants tended to be more dominant in ethyl acetate extract although not significantly different $(\mathrm{P}>0.05)$. The anti-oxidant analysis results are slightly different from the Khalili et al. [37] study, which showed the highest bioactive component found in ethyl acetate extract. Hexane can attract fat components, terpenoids, steroids, and carotenoids. Semipolar ethyl acetate solvents dissolve proteins, xanthones, alkaloids, flavonoids, and polyphenols, while water can attract compounds such as carbohydrates (glycosides), phenolics, saponins, and tannins. The mature winged bean of our study had moisture, protein, carbohydrate by difference, fat, ash and a phenolic total of 13.01 \pm 0.07 ,
$38.91 \pm 0.06, \quad 40.82 \pm 0.11, \quad 15.40 \pm 0.06, \quad 4.85 \pm 0.03 \quad \%$, $7.67 \pm 0.29 \mathrm{mgGAE} / \mathrm{g}$ [7].

\section{B. Lymphocyte Cell Proliferation Activity}

The lymphocyte culture results showed a change in the number of cells after the addition of winged extract. The highest proliferation index is found in processed bean and canned beans in water extract with a value of 2.13 . This number means that the addition of $20 \%$ of processed bean water extract with a concentration of $3.2 \mathrm{mg} / \mathrm{mL}$ into cell cultures can increase the cell count by 2.13 times from the initial amount. The lowest proliferation index was found in vegetable winglets in ethyl acetate extract with a concentration of $2.77 \mathrm{mg} / \mathrm{mL}$ with a value of 0.7 . A proliferation index number of less than 1 indicates the presence of cells that died during culture (Figure 1).
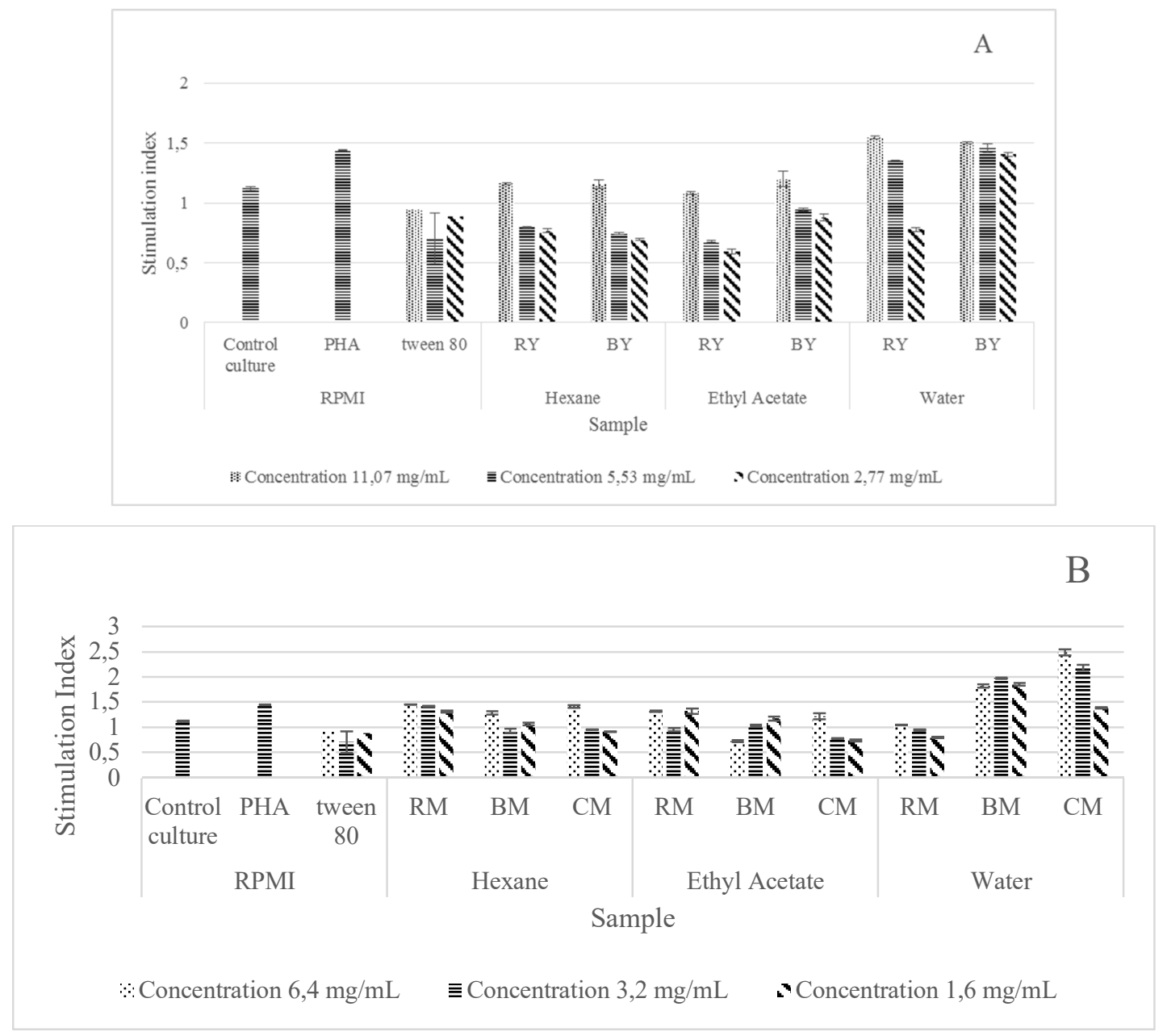

Fig. 1 The average of winged bean extract stimulation index at various concentrations of three replications. *A) Extracts of young winged beans; B) Extracts of mature winged bean. $\mathrm{RY}=$ raw young winged bean; $\mathrm{BY}=$ boiled young winged bean; $\mathrm{RM}=$ raw mature winged bean; $\mathrm{BM}=$ boiled mature winged bean; $\mathrm{CM}=$ canned mature winged bean

The average proliferation index value for winged beans (1.31) was higher than for vegetable winglets (1.04) and positive controls (1.09). Nevertheless, the average vegetable proliferation index value was relatively higher than the negative control (1.00). Positive control uses PHA which is a red bean lectin and acts as a mitogen. Mitogen is a compound that can activate the signal transduction system to induce multiplication of lymphocyte cells both $\mathrm{T}$ cells, B cells and natural killer cells (NK). The winged bean stimulation indexes were more than that of the positive control and it was assumed that besides the presence of lectins there were also more complex bioactive components such as flavonoids, tannins, short-chain fatty acids (SCFA) and peptides in the beans.

The processing factor significantly $(\mathrm{P}<0.5)$ increased the proliferation index of processed winged and vegetable beans. The bioactive component is always toxic if given at high doses but has the benefit of being a drug at the right low dose. 
In ethyl acetate and hexane extract there are steroid compounds, terpenoids, and coumarin which are toxic although, on the other, hand they can also act as anticancer[38]. The concentration of extracts statistically (P $<0.5)$ gave a different response where the higher the concentration the higher the cell stimulation index value. In this study extract concentrations were calculated based on WHO recommendations on the amount of daily consumption of vegetables and grains so that the amount of the bioactive compounds in the culture could represent the amount of bioactive compound absorbed in the blood [19].

\section{Production of Interleukin 2 (IL-2) by Lymphocyte Cells}

Increased production of lymphocyte IL-2 is in line with positive controls although not significantly different $(\mathrm{P}>0.05)$. The type of beans and the processing carried out on winged beans did not provide a significant difference $(\mathrm{P}>0.05)$ (Figure 2).

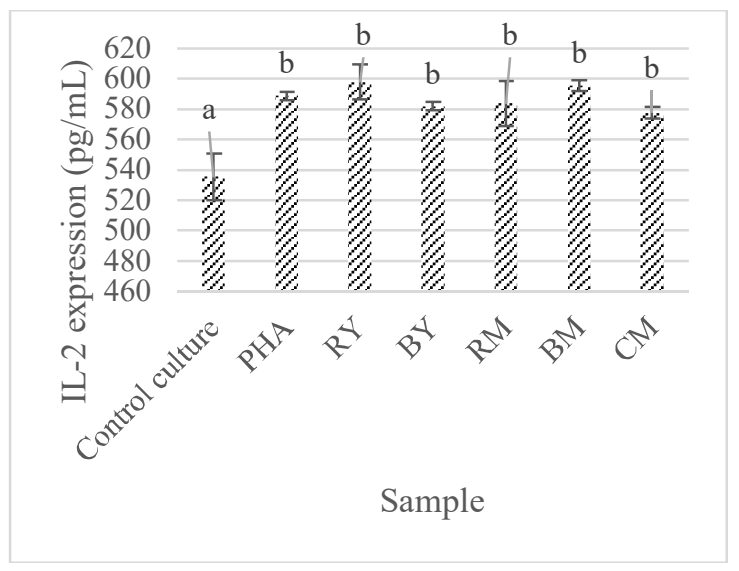

Fig. 2 Expression of IL-2 lymphocyte cultured with winged vegetable and bean extracts.

Notes: Cells with the addition of winged bean in water extract concentration of $5.53 \mathrm{mg} / \mathrm{mL}$ in young winged beans and $3.2 \mathrm{mg} / \mathrm{mL}$ in mature beans. $\mathrm{RY}=$ raw young winged bean; $\mathrm{BY}=$ boiled young winged bean; $\mathrm{RM}=$ raw mature winged bean; $\mathrm{BM}=$ boiled mature winged bean; $\mathrm{CM}=$ canned mature winged bean. Different letters showed significant differences based on the Duncan Post hoc test $(\mathrm{P}<0.05)$.

This can be interpreted that both young winged bean pods and bean have positive effects on IL-2 synthesis in human lymphocyte culture. IL-2 is a group of haemopoietin produced by Th cells to increase immune cell functions, including proliferation activities.

\section{Numbers of CD4+T Cell, CD8+TCell, CD3+TCell,} CD19+BCell and CD16+ / 56+TCell (NK Cell)

The cluster of differentiation (CD) is a cell surface molecule expressed by immune cells and used as a marker in immunophenotyping [21]. The determination of the number of CD4+ and CD8+ subset cells was carried out based on the principle of antibody reactions. Cell pellets from culture were added with FITC-anti-human CD3+, PE-Cy7-A -anti-human CD4+, APC-Cy7-A-anti-human CD8+, APC-A-anti-human CD19+ and PE- A -anti-human CD16 / 56+. Colour illumination will appear when the colored anti-human subset binds to the tested cell suspension's human subset. The flowcytometer captures the luminescence carried by the sample stream and is translated in the form of dot plots in different quadrants.

Based on the data in Table 2, it can be concluded that vegetable and winged bean boiled or canned did not give a significant change $(\mathrm{P}<0.05)$ to the number of $\mathrm{CD} 4+$ and $\mathrm{CD} 8+$ subsets. This shows that winged bean extracts did not specifically induce the multiplication of these subset cells. An increase in the CD4+ subset cell indicates the number of $\mathrm{T}$ helper cells (Th) that act as B cells' stimulators to produce antibodies and a marker for HIV virus infection. The CD8 + subset indicates the presence of cytotoxic cells (Tc) which play a role in the body's defense mechanism against other mutated cells such as cancer cells, viruses and microbes infected cells [21].

TABLE II

NUMBER OF CD3,+ CD4,+ CD8,+ CD $19+$, CD 16/56 SUBSET CELLS

\begin{tabular}{cccccc}
\hline Sample & CD4+ Tcells (\%) & CD8+ Tcells (\%) & CD3+Tcells (\%) & CD19+Bcells (\%) & CD16/56 NK cells (\%) \\
\hline Control & $27.72 \pm 3.31^{\mathrm{c}}$ & $22.75 \pm 0.42^{\mathrm{b}}$ & $55.02 \pm 3.19^{\mathrm{b}}$ & $13.84 \pm 1.66^{\mathrm{bc}}$ & $63.42 \pm 3.83^{\mathrm{ab}}$ \\
culture & $13.35 \pm 0.11^{\mathrm{b}}$ & $31.14 \pm 2.0^{\mathrm{c}}$ & $47.90 \pm 2.54^{\mathrm{b}}$ & $13.73 \pm 0.48^{\mathrm{bc}}$ & $58.06 \pm 2.38^{\mathrm{a}}$ \\
PHA & $32.46 \pm 3.18^{\mathrm{c}}$ & $20.76 \pm 2.15^{\mathrm{b}}$ & $55.99 \pm 0.63^{\mathrm{b}}$ & $13.65 \pm 1.16^{\mathrm{bc}}$ & $62.66 \pm 1.56^{\mathrm{ab}}$ \\
RY & $29.59 \pm 1.08^{\mathrm{c}}$ & $21.55 \pm 0.62^{\mathrm{b}}$ & $55.78 \pm 1.52^{\mathrm{b}}$ & $15.85 \pm 0.19^{\mathrm{c}}$ & $58.14 \pm 2.75^{\mathrm{a}}$ \\
BY & $28.33 \pm 3.65^{\mathrm{c}}$ & $21.54 \pm 3.59^{\mathrm{b}}$ & $55.27 \pm 7.08^{\mathrm{b}}$ & $11.92 \pm 0.39^{\mathrm{b}}$ & $63.43 \pm 2.93^{\mathrm{b}}$ \\
RM & $27.91 \pm 0.15^{\mathrm{c}}$ & $22.39 \pm 0.62^{\mathrm{b}}$ & $54.33 \pm 0.71^{\mathrm{b}}$ & $9.39 \pm 0.35^{\mathrm{a}}$ & $71.71 \pm 0.27^{\mathrm{c}}$ \\
BM & $29.04 \pm 1.13^{\mathrm{c}}$ & $21.53 \pm 1.25^{\mathrm{b}}$ & $55.81 \pm 1.72^{\mathrm{b}}$ & $12.69 \pm 0.21^{\mathrm{b}}$ & $67.68 \pm 1.56^{\mathrm{bc}}$ \\
CM & &
\end{tabular}

$\mathrm{RY}=$ raw young winged bean; $\mathrm{BY}=$ boiled young winged bean; $\mathrm{RM}=$ raw mature winged bean; $\mathrm{BM}=$ boiled mature winged bean; $\mathrm{CM}=$ canned mature winged bean. Values are mean \pm SEM from triplicate analyses. Different letters showed significant differences based on the Duncan post hoc test $(\mathrm{P}<0.05)$.

CD3+Tcells number in Table 2 was not significantly different $(\mathrm{P}>0.05)$ in both the control cells and the treated cultures. Significant differences $(P<0.05)$ were shown with boiled winged vegetables with the highest total CD19+Bcells $(15.85 \%)$ and boiled mature bean at the highest total CD16 / $56+$ Tcells $(71.71 \%)$. The percentage value of each $\mathrm{CD}$ was obtained from the number of CDs compared to detectable lymphocyte cell populations. It appeared that the lymphocytes that proliferated (Figure 1) were mostly CD19+Bcells and CD16 / 56+Tcells. These indicate the potentials of winged bean consumption in improving antibody synthesis by CD19+Bcells and cancer and virus infection prevention by CD16 / 56+Tcells or NK according to both cell type activities in performing their specific functions. The capacity of improving the immune system and cancer prevention through 
NK cell function by bean products has been demonstrated in many research [20], [39].

\section{CONCLUSION}

Both young winged bean pods and mature bean extracts had positive effects on anti-oxidant activity and were able to increase the proliferation of lymphocytes. Anti-oxidant activity and proliferation index of winged beans were higher than those of young winged bean pods. The highest antioxidant and proliferation activity of the winged bean was found in the water extract. Boiled young winged bean pods and boiled mature bean water extracts appeared to stimulate lymphocytes proliferation and the proliferated cells were mostly CD19+Bcells and CD16 / 56+Tcells. It can be concluded that the consumption of young winged bean pods and winged beans may contribute to improving antibody synthesis by CD19+Bcells and cancer and virus infection prevention by CD16 / 56+Tcells or NK cells. Nevertheless, further investigation on the mechanism of the lymphocyte cell stimulations may be interesting to perform.

\section{ACKNOWLEDGMENT}

The researchers are grateful to the Ministry of Research and Technology of the Republic of Indonesia (KEMENRISTEK DIKTI) for providing research funding through the Higher Education Applied Program (PTUPT) under Prof. Fransiska R. Zakaria. M.Sc with project number 1658 / IT3.11 / PN / 2018.

\section{REFERENCES}

[1] BPS, "Percentage of population having health complaints in the last month by province, 2000-2017," 2017, 2017.

[2] H. Cena and P. C. Calder, "Defining a Healthy Diet: Evidence for the Role of Contemporary Dietary Patterns in Health and Disease," Nutrients, vol. 12, no. 2, p. 334, Jan. 2020.

[3] K. H. Al-Gubory, "Introducing chapter: Phytochemicals, anti-oxidant therapy, opportunities and challenges," in Nutritional Anti-oxidant Therapies: Treatments and Perspectives, Springer International Publishing, 2018, pp. 1-26.

[4] S. G. J. van Breda and T. M. C. M. de Kok, "Smart Combinations of Bioactive Compounds in Fruits and Vegetables May Guide New Strategies for Personalized Prevention of Chronic Diseases," Mol. Nutr. Food Res., vol. 62, no. 1, p. 1700597, Jan. 2018.

[5] X. Dong et al., "Combined utilization of untimed single urine of MCP1 and TWEAK as a potential indicator for proteinuria in lupus nephritis: A case-control study," Med. (United States), vol. 97, no. 16, Apr. 2018.

[6] I. Yulianah, B. Waluyo, S. Ashari, and Kuswanto, "Variation in morphological traits of a selection of Indonesian winged bean accessions (Psophocarpus tetragonolobus) and its analysis to assess genetic diversity among accessions," Biodiversitas, vol. 21, no. 7, pp. 2991-3000, Jul. 2020

[7] R. D. Setyawan, F. R. Zakaria, and A. B. Sitanggang, "Karakteristik Kimia Fungsionalitas Kecipir pada Waktu Panen Berbeda di Kabupaten Bogor," J. Teknol. dan Ind. Pangan, vol. 8, 2019.

[8] P. Lepcha, A. N. Egan, J. J. Doyle, and N. Sathyanarayana, “A Review on Current Status and Future Prospects of Winged Bean (Psophocarpus tetragonolobus) in Tropical Agriculture," Plant Foods for Human Nutrition, vol. 72, no. 3. Springer New York LLC, pp. 225235, Sep-2017.

[9] M. U. Makeri, F. Abdulmannan, M. A. Ilowefah, C. Chiemela, S. M. Bala, and K. Muhammad, "Comparative physico-chemical, functional and structural characteristics of winged bean [Psophocarpus tetragonolobus DC] and Soybean [Glycine max.] Protein isolates," $J$. Food Meas. Charact., vol. 11, no. 2, pp. 835-846, Jun. 2017.

[10] A. Cheng, M. N. Raai, N. A. M. Zain, F. Massawe, A. Singh, and W. A. A. Q. I. Wan-Mohtar, "In search of alternative proteins: unlocking the potential of underutilized tropical legumes," Food Security, vol. 11, no. 6. Springer, pp. 1205-1215, Dec-2019.
[11] J. Calvindi, M. Syukur, and W. Nurcholis, "Investigation of biochemical characters and anti-oxidant properties of different winged bean (Psophocarpus tetragonolobus) genotypes grown in Indonesia," Biodiversitas, vol. 21, no. 6, pp. 2420-2424, Jun. 2020.

[12] S. N. Amrizal, F. R. Zakaria, Suliantari, and E. Chasanah, "Consumption of Purple Soy Tofu in Improving Hyperglycemia Condition and Nutritional Intake to Type-2 Diabetes Mellitus Respondents," Int. J. Adv. Sci. Eng. Inf. Technol., vol. 8, no. 5, pp. 2065-2070, 2018.

[13] T. K. Koley et al., "Anti-oxidant potential of commonly consumed underutilized leguminous vegetables," Int. J. Veg. Sci., vol. 25, no. 4, pp. 362-372, Jul. 2019.

[14] S. Y. Chay et al., "Blood-pressure lowering efficacy of winged bean seed hydrolysate in spontaneously hypertensive rats, peptide characterization and a toxicity study in Sprague-Dawley rats," Food Funct., vol. 9, no. 3, pp. 1657-1671, Mar. 2018.

[15] H. Bassal, O. Merah, A. M. Ali, A. Hijazi, and F. El Omar, "Psophocarpus tetragonolobus: An Underused Species with Multiple Potential Uses," Plants, vol. 9, no. 12, p. 1730, Dec. 2020.

[16] F. R. Zakaria, Nurahman, E. Prangdimurti, and Tejasari, "Anti-oxidant and immunoenhancement activities of ginger (Zingiber officinale Roscoe) extracts and compounds in in vitro and in vivo mouse and human system," Nutraceutical and Foods, vol. 8, pp. 96-104, 2003.

[17] B. Singh, J. P. Singh, A. Kaur, and N. Singh, "Phenolic composition and anti-oxidant potential of grain legume seeds: A review," Food Research International, vol. 101. Elsevier Ltd, pp. 1-16, Nov-2017.

[18] B. Baby, P. Antony, and R. Vijayan, "Anti-oxidant and anticancer properties of berries," Critical Reviews in Food Science and Nutrition, vol. 58, no. 15. Taylor and Francis Inc., pp. 2491-2507, Oct-2018.

[19] R. F. Hasrini, F. R. Zakaria, D. R. Adawiyah, and I. H. Suparto, "Antidiabetic and Immunomodulatory Potential of Purple Soymilk Enriched with Crude Palm Oil Microcapsule in Type- 2 Diabetes Mellitus Respondents,” Malays. J. Nutr., vol. 23, no. 3, pp. 461-471, 2017.

[20] M. Grudzien and A. Rapak, "Effect of Natural Compounds on NK Cell Activation," J. Immunol. Res., vol. 2018, pp. 1-11, Dec. 2018.

[21] P. J. Delves, S. J. Martin, D. R. Burton, and I. M. Roitt, Roitt's Essential Immunology 13th Edition, 13th ed. London: John Wiley \& Sons, Inc, 2017.

[22] N. M. Ali et al., "Comparison of free amino acids, anti-oxidants, soluble phenolic acids, cytotoxicity and immunomodulation of fermented mung bean and soybean," J. Sci. Food Agric., vol. 96, no. 5, pp. 1648-1658, 2016.

[23] W. M. Umeda, D. M. Moreno Luzia, and N. Jorge, "Evaluation of Bioactive Compounds in Bean Oils (Phaseolus vulgaris L.), Perola and BRS Valente Varieties," Curr. Nutr. Food Sci., vol. 14, no. 1, pp. 4046, Jan. 2018.

[24] S. Bi et al., "Effect of cooking on aroma profiles of Chinese foxtail millet (Setaria italica) and correlation with sensory quality," Food Chem., vol. 289, pp. 680-692, Aug. 2019.

[25] T. A. Vargas-Salazar, K. A. Wilkinson, J. M. Urquiaga-Zavaleta, and A. R. Rodríguez-Zevallos, "Physicochemical characterization of $\tilde{N} u \tilde{N} a$ bean (Phaseolus vulgaris 1.) protein extract," Vitae, vol. 27, no. 2, Aug. 2020.

[26] S. Guillén, J. Mir-Bel, R. Oria, and M. L. Salvador, "Influence of cooking conditions on organoleptic and health-related properties of artichokes, green beans, broccoli and carrots," Food Chem., vol. 217, pp. 209-216, Feb. 2017.

[27] R. A. Vargas, C. P. Malacara, and V. L. Petricevich, "Characterization of chemical compounds with anti-oxidant and cytotoxic activities in bougainvillea x buttiana Holttum and Standl, (var. Rose) extracts," Anti-oxidants, vol. 5, no. 4, p. 45, 2016.

[28] A. M. Muddathir, K. Yamauchi, I. Batubara, E. A. M. Mohieldin, and T. Mitsunaga, "Anti-tyrosinase, total phenolic content and anti-oxidant activity of selected sudanese medicinal plants," South African J. Bot., vol. 109, pp. 9-15, 2017.

[29] Erniati, F. R. Zakaria, and B. P. Priosoeryanto, "Efek Konsumsi Minuman Bubuk Kakao (Theobroma cacao L.)Bebas Lemak terhadap Sifat Antioksidatif Limfosit Subyek Perempuan," J. Teknol. dan Ind. Pangan, vol. 23, no. 1, p. 81, 2012.

[30] F. R. Zakaria, E. Prangdimurti, K. D. Puspawati, R. Thahir, and Suismono, "Diet Berbasis Sorgum (Sorghum bicolor L Moench) Memperbaiki Proliferasi Limfosit Limfa dan Kapasitas Antioksidan Hati Tikus," Pangan, vol. 20, no. 3, pp. 209-221, 2011.

[31] W. Li et al., "Clonorchis sinensis Co-infection Could Affect the Disease State and Treatment Response of HBV Patients," PLOS Neglected Trop. Dis., vol. 10, no. 6, pp. 1-15, 2016. 
[32] S. Gujral, K. P. C. Sharma, P. Gupta, and A. Wani, "Anti-oxidants properties of legumes and their morphological fractions as affected by cooking," Food Sci. Biotechnol., vol. 22, no. 1, pp. 187-194, 2013.

[33] D. F. Holderbaum, T. Kon, and M. P. Guerra, "Scientia Horticulturae Dynamics of total phenolic content in different apple tissues and genotypes : impacts and relevance for breeding programs," Sci. Hortic. (Amsterdam)., vol. 168, pp. 58-63, 2014.

[34] S. Boukhanouf, H. Louaileche, and D. Perrin, "Phytochemical content and in vitro anti-oxidant activity of faba bean (Vicia faba L.) as affected by maturity stage and cooking practice," Int. Food Res. J., vol 23, no. 3, pp. 954-961, 2016.

[35] V. E. Nambi, R. K. G. Sunil, and K. P. C. Sharma, "Degradation Kinetics of Bioactive Components, Anti-oxidant Activity, Colour and Textural Properties of Selected Vegetables During Blanching," $J$.
Food Sci. Technol., vol. 53, no. 7, pp. 3073-3082, 2016.

[36] A. Nirbaya, F. R. Zakaria, and H. Wijaya, "Stability of Bioactive Compound And Fatty Acid Composition After Thermal Processing of Winged Bean (Psophocarpus tetragonolobus)," Int. J. Adv. Sci. Technol., vol. 29, no. 7, pp. 1602-1610,2020.

[37] R. M. A. Khalili et al., "Total Phenolic Content and In Vitro Antioxidant Activity of Winged Bean (Psophocarpus tetragonolobus),' Pakistan J. Nutr., vol. 12, no. 5, pp. 416-422, 2013.

[38] N. Nazir, M. Zahoor, and M. Nisar, "A Review on Traditional Uses and Pharmacological Importance of Genus Elaeagnus Species," Bot. Rev., vol. 86, no. 3-4, pp. 247-280, Dec. 2020.

[39] D. Hou et al., "Mung Bean (Vigna radiata L.): Bioactive Polyphenols, Polysaccharides, Peptides, and Health Benefits," Nutrients, vol. 11, no. 6, p. 1238, May 2019. 